\title{
The diurnal primate community of the Tanoé Forest: species composition, relative abundance, distribution, polyspecific associations and conservation status
}

\author{
Jean-Claude Koffi BENE ${ }^{1,2 *}$, Inza KONE ${ }^{1,3}$, Sery GONEDELE BI ${ }^{1,4}$, \\ Eloi Anderson BITTY ${ }^{1,3}$, Karim OUATTARA ${ }^{1,3}$, Kouamé Bertin AKPATOU ${ }^{1,3}$, \\ Kouamé Antoine N'GUESSAN ${ }^{1,3}$ and Djaha André KOFFI ${ }^{1,2}$ \\ ${ }^{1}$ Centre Suisse de Recherches Scientifiques en Côte d'Ivoire, 01 BP 1303 Abidjan 01 \\ ${ }^{2}$ Unité Pédagogique et de Recherche de Biologie et Physiologie Animale, \\ URES Daloa, Côte d'Ivoire, BP 150 Daloa. \\ ${ }^{3}$ Laboratoire de Zoologie, Université de Cocody-Abidjan, Côte d'Ivoire, 22 BP 582 Abidjan 22 \\ ${ }^{4}$ Laboratoire de Génétique, Université de Cocody-Abidjan, Côte d'Ivoire, 22 BP 582 Abidjan 22 \\ ${ }^{5}$ Conservation des Espèces et Populations Animales, France. \\ "Corresponding author,E-mail : jc_bene@yahoo.frorbenejc@gmail.com, Mobile : +22502499947। \\ $+22505983717$
}

\begin{abstract}
The Tanoé Forest is located within the original distribution area of the Miss Waldron red colobus (Piliocolobus badius waldronae), the diana roloway (Cercopithecus diana roloway) and the white napped mangabey (Cercocebus atys lunulatus). These three monkey species are classified by IUCN among the 25 most threatened monkeys of the world. Surveys conducted in their believed distribution area in Côte d'Ivoire from 2004 to 2007 highlighted an advanced degradation of habitats, an intensive hunting activity and a subsequent local extinction of some primate species. Field survey conducted in the Tanoé Swamp Forest shown that there is an exception in this dramatic context since this forest still housing threatened species such as the Diana roloway, the white-napped mangabey, and other monkeys of conservation concern : the Geoffroy's colobus (Colobus vellerosus) and the olive colobus (Procolobus verus), and probably a viable Miss Waldron monkeys population (Piliocolobus waldronae). In addition, this forest hosts the Lowe's guenon (Cercopithecus campbelli lowei) and the lesser spot-nosed guenon (Cercopithecus petaurista petaurista), that are widespread in the Tanoé Swamp Forest.
\end{abstract}

() 2012 International Formulae Group. All rights reserved.

Keywords: Tanoé forest, primate community, endangered, Swamp Forest, distribution.

\section{INTRODUCTION}

The coastal forest ecosystems from Guinea to Nigeria have been defined as a hotspot because it contains a high level of species diversity and endemism. It belongs to the twenty five world's most threatened ecosystem (Myers et al., 2000). Côte d'Ivoire is part of this region and presents one of the highest diversity in primate species in West Africa with twenty three known species. One 
of them is endemic to the country and three others are endemic to both Côte d'Ivoire and Ghana. However, logging, hunting and human population growth have resulted unprecedented forest fragmentation and forest losses. Indeed, in 1957, the forest estate was estimated at 21 million hectares. In 1995, the area covered by forest was less than 2.8 million hectares (Yao et al., 2005). In addition to some environmental problems that this situation creates, we are witnessing the disappearance of many animal and plant species in most parts of the country. These species continue to be threatened even in national parks and reserves by intensive poaching and inappropriate conservation measures. Cowlishaw (1999) studied the potential relationship existing between habitat loss and population extinction. He suggested that this extinction occurred for over $30 \%$ of the forest primates in Africa. By considering the rate of deforestation and species loss, Côte d'Ivoire has the highest rates among the top five countries. These countries are predicted to lose $40-50 \%$ of their primate species.

The primates have been well studied in the western part of Côte d'Ivoire, particularly in the Taï National Park, where long-term field studies have been going on over years. Indeed, Taï Chimpanzee Project (TCP) and Taï Monkey Project (TMP) contribute to the preservation of the primate species occurring in this part of the country through ecological, ethological and genetic studies. However, in other parts of the country, studies on primates are scarce. Only rapid surveys have been conducted in the eastern part of this country (McGraw et al., 1998; Oates et al., 2000; McGraw, 2005; Gonédélé Bi et al., 2008; McGraw and Oates, 2009; Gonedelé Bi et al., 2010).

The South-central and eastern Côte d'Ivoire in the eastern part of the Upper Guinea forests hotspot are reported to be part of the original range of three critically endangered primate species: the Diana roloway (Cercopithecus diana roloway), the white-napped mangabey (Cercocebus atys lunulatus) and the Miss Waldron's red colobus (Piliocolobus badius waldronae). However, no significant conservation effort has been carried out so far on behalf of these monkeys while by, they are increasingly threatened by human activities. Updates on the current distribution and conservation status of these primates and the identification of sites for primate conservation are urgently needed.

As result of these surveys, the Tanoé Forest has been identified as a priority site for endangered primates conservation in West Africa (Gonédélé Bi et al., 2008), since this forest inhabits several endangered species comprising Cercopithecus Diana roloway, Cercocebus atys lunulatus, Colobus vellerosus. The Tanoé Swamp Forest may also represent the latest refugee of Piliocolobus badius waldronae, since there is strong evidence that the species has survived in this forest (McGraw, 2005). But, only five days were spent in this forest during the first study. The aims of this present survey are to (i) confirm the specific composition of the diurnal primate communities and (ii) determine the relative abundance of these species, (iii) their distribution in this forest, (iv) the poly-specific association in which they involve and identify (v) their conservation status. Thirty days survey period was conducted in this forest for this purpose.

\section{MATERIALS AND METHODS}

\section{Survey site}

The Tanoé Forest is located in the South-eastern corner of Côte d'Ivoire between latitudes north $5^{\circ} \quad 05^{\prime}$ and $5^{\circ} 15^{\prime}$ and longitudes west $2^{\circ} 45^{\prime}$ and $2^{\circ} 53^{\prime}$ (Figure 1). The average rainfall in the region was 1925 mm per year (Avenard et al., 1971) but it has decreased considerably over the last five 
years. It fluctuated between 1400 and 1600 $\mathrm{mm}$ per year. The temperatures range from $22^{\circ} \mathrm{C}$ to $30^{\circ} \mathrm{C}$ with an average of $26^{\circ} \mathrm{C}$ (Adou Yao, 2007). The Tanoé Forest is covered by evergreen forest vegetation on swamp ground. The forest is inundated most of the year. Even during the dry season (January, February and March), it is difficult to move through the forest without being trapped into the mud.

This forest is in the rural domain and does not benefit any measure of protection from the authorities of Côte d'Ivoire. It owes its survival mainly from it swamp state that does not allow the villagers to grow crops, but also from its importance for these populations. Indeed, it constitutes the place of supply of the people in fish, bushmeat and various construction materials. For these reasons, the community has consistently opposed to all industrial institutions (forester, industrial farmers ...) wanting to use the forest
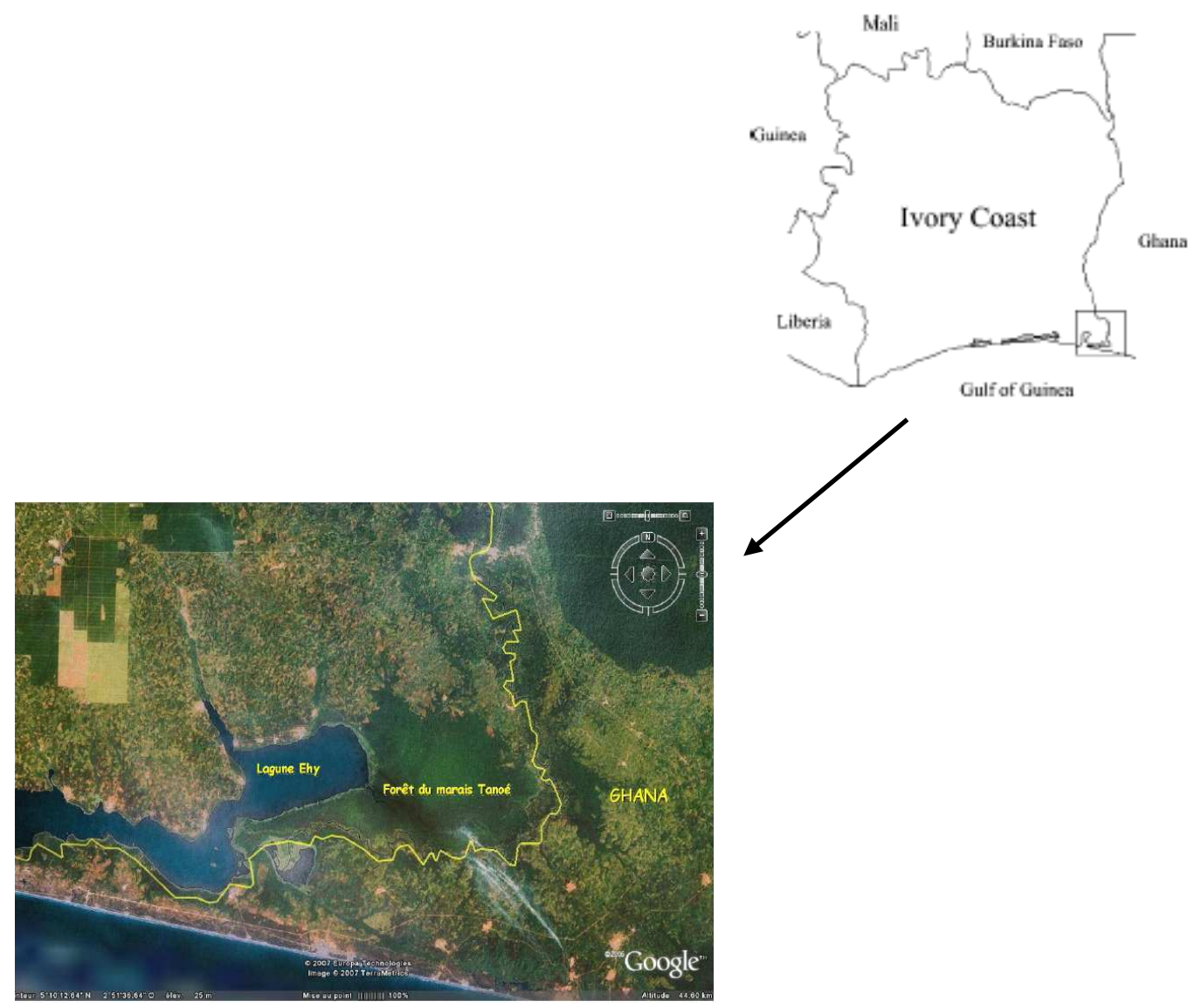

Figure 1: Location of the Tanoé Swamp Forest in South Eastern Côte-d'Ivoire. 


\section{Methods}

Forest survey was made on foot consisting on walking slowly and quietly along old logging roads and existing paths with $0.8-1 \mathrm{~km} / \mathrm{hour}$. The mean distance traveled was about ten kilometers per day and the same walk was repeated twice on the daily basis. Two field works were conducted in the forest in 2007 (13-27 $7^{\text {th }}$ february 2007) and in $2008\left(15^{\text {th }}\right.$ february to $25^{\text {th }}$ march 2008) respectively. During the 2007 survey, two camps were established successively with four primatologists and eight guides. During the 2008 survey, a total of eight researchers and 16 guides were mobilized in two different camps simultaneaously. Every morning four teams of three persons took different directions from each camp. Guide teams were constituted by former hunters transformed into forest guards by RASAP-CI. Each team changed its camp twice, a total of six camps throughout the forest were established, in order to prospect the majority of the forest. We took note of any visible and audible signs of the presence of primates and determined its position with a GPS. When animals were encountered during the surveys, we determined the species and counted individuals (when possible). We start early in the morning at $6 \mathrm{~h} 00$ and continue until $1 \mathrm{~h} 00$ p.m.. After resting for 1 hour we can then continue the exercise till $6 \mathrm{~h} 30$ p.m.

\section{Data analysis}

Apart from the establishment of the distribution maps for different groups of monkeys observed, all other analysis consisted of calculating frequencies using Excel software. Thus, the distribution of groups was determined by recording the geographic coordinates of these groups that were then projected onto a base map of the forest using the software MapInfo Professional. Species identification was made directly on the field as all team members known very well monkey species. We also calculated the frequencies of encounter rate (number of observations per time of observation). Relative abundance was calculated (number of groups per the distance covered to observe these groups and for the poly-specific association, only frequencies of associations have been calculated.

\section{RESULTS}

Specific composition of the primate community of the Tanoé forest

We confirmed the presence of seven diurnal primate species or subspecies in the Tanoé forest:

Three of them are critical endangered (Miss Waldron red colobus, Diana Roloway, White-napped mangabey), two are near threatened (Geoffroy white thighed colobus, Olive colobus) and two are common (Lowe's guenon, Lesser spot-nosed monkey). Except Miss Waldron's red colobus monkeys, several observations of different groups were done during the survey (Table 1).

The Lowe's monkeys (Cercopithecus campbelli lowei) are among the most widespread primates living in the Tanoe Swamp Forest. They can be found in all parts of the forest. A total of 123 groups have been identified in 155 observations during the surveys. The most observations were audible signs with $67.64 \%$ or visual signs $(32.26 \%)$ (Table 1).

The Lesser spot-nosed monkey (Cercopithecus petaurista petaurista) and the Campbell's monkeys represent the most widespread primate taxa in the Tanoe Swamp Forest. We observed 71 groups of this monkey in 82 signs, $\mathrm{N}=52(63.41 \%)$ were visual against $\mathrm{N}=30(35.19 \%)$ audible observations (Table 1).

New evidence of the Miss Waldron Red Colobus (Piliocolobus badius waldronae) suggests that this species still existing in the Tanoe Swamp Forest. Only few vocalizations were heared by some members of the teams during the surveys in the most wet part of this forest, near the lagoon.

We identified 69 groups of the Diana roloway monkey (Cercopithecus diana roloway) in 85 observations. To date, only the Tanoe Swamp Forest still inhabiting several 
groups of $C$. $d$. roloway. We were very happily surprise to encounter so many groups of Diana roloway monkeys in this forest, $\mathrm{N}=$ $47(55.30 \%)$ were audible and $\mathrm{N}=38$ $(44.70 \%)$ of this eveidence were sighted (Table 1). Here, this monkeys is widspreed (Figure 2a) like the common monkeys (Campbell lowe and lesser spot-nosed).

In addition, the Tanoé Swamp Forest inabits an importante population of Whitenapped mangabey (Cercocebus atys lunulatus). We observed 45 signs of this species in this forest and allowed to identify 37 groups (figure 2b). Audible observations represent $71.11 \%$ against $26.66 \%$ for sighted and $02.23 \%$ for feeding tracks (Table 1).

The Geoffroy White-thighed Colobus is also confirmed in the Tanoe Swamp Forest. We found 26 groups in this swamp forest in 26 obervations (figure $3 a$ ) and $65.40 \%(\mathrm{~N}=$ 17) of these observations were visual against $34.60 \%(\mathrm{~N}=9)$ audible contacts (Table 1).

For the Olive Colobus (Procolobus verus) 24 groups were identified (figure $3 \mathrm{~b}$ ) in 29 observations. The observations were mostly visual $(55.17 \%)$ and audible contacts represent $44.83 \%$ of the total observation (Table 1).

\section{Frequency of primate encounters and relative abundance}

Over the 423 observations of primate evidences that we made in 748 hours in the Tanoé Forest (0.56 obs./hour), only $0.25 \%$ $(\mathrm{N}=1)$ was indirect (feeding tracks of whitenapped mangabey). Direct contacts (visual or auditory contact) were the most frequent with $99.75 \%(\mathrm{~N}=422)$. A total of 496 kilometers have been made by the different teams during the survey time in the Tanoé Forest. By analyzing the encounter rate, three categories can be proposed (Table 2):

"The most encountered" species in the Tanoé Forest are the Campbell's Lowe, the Roloway Diana guenon and the Lesser Spotnosed monkey. For Campbell's Lowe, N = 155 observations were made during the survey with an Encounter rate $\mathrm{E}=0.36 \mathrm{obs} /$ hour. The Roloway Diana guenon represents the seconds species in this category with 85 observations in 748 hours $(E=0.20$ obs/hour $)$. For the Lesser Spot-nosed monkey $\mathrm{N}=82$ observations were made with $\mathrm{E}=0.94$ obs/hour). When we consider the relative abundance we can note that the Campbell's guenons, the Lesser Spot-nosed monkey and the Roloway Diana guenon are the most abundant monkey species living in the Tanoé Forest with respectively 0.24 group $/ \mathrm{km}, 0.14$ group $/ \mathrm{km}$ and 0.13 group $/ \mathrm{km}$.

The second category is the "lower encountered" of monkey species formed by the White-napped mangabey ( $0.10 \mathrm{obs} /$ hour $)$, the Olive colobus ( $0.07 \mathrm{obs} / \mathrm{hour})$ and the Geoffroy's colobus (0.06 obs/hour). Comparing the relative abundance, the White napped mangabey $(0.07$ group $/ \mathrm{km})$ is the fourth monkey species of the Tanoé Forest, the Geoffroy white thighed colobus $(0.05$ group $/ \mathrm{km}$ ) is the fifth and Olive colobus monkey with 0.04 group $/ \mathrm{km}$ is the sixth.

The Miss Waldron red colobus constitutes alone the third category of monkey with "rare encounter" frequency and represents the last monkey species of the Tanoé Forest in abundance level. Indeed, during the total times of observation, only few audible signs were recorded $(\mathrm{N}=1)$ and $\mathrm{E}=$ $0.02 \mathrm{obs} /$ hour) with a relative abundance of 0.02 group $/ \mathrm{km}$.

\section{Polyspecific associations}

During the surveys, these different groups of monkeys have been observed in polyspecific associations. The most encountered associations were made with the Roloway Diana guenon, the White napped mangabey and the Olive colobus monkeys species. Tables 3 and 4 show the different associations according to the species, the type of observation and the GPS coordinates (Table 3), the number of observation and the frequency of association (Table 4). The dominant polyspecific association is made by Roloway Diana guenon and White napped mangabey with $45.45 \%(\mathrm{~N}=10)$, followed by the Roloway Diana guenon and Olive colobus with $31.82 \%(\mathrm{~N}=7)$ and the association of Olive colobus and the Geoffroy pied monkey with $09.11 \%(\mathrm{~N}=2)$. 


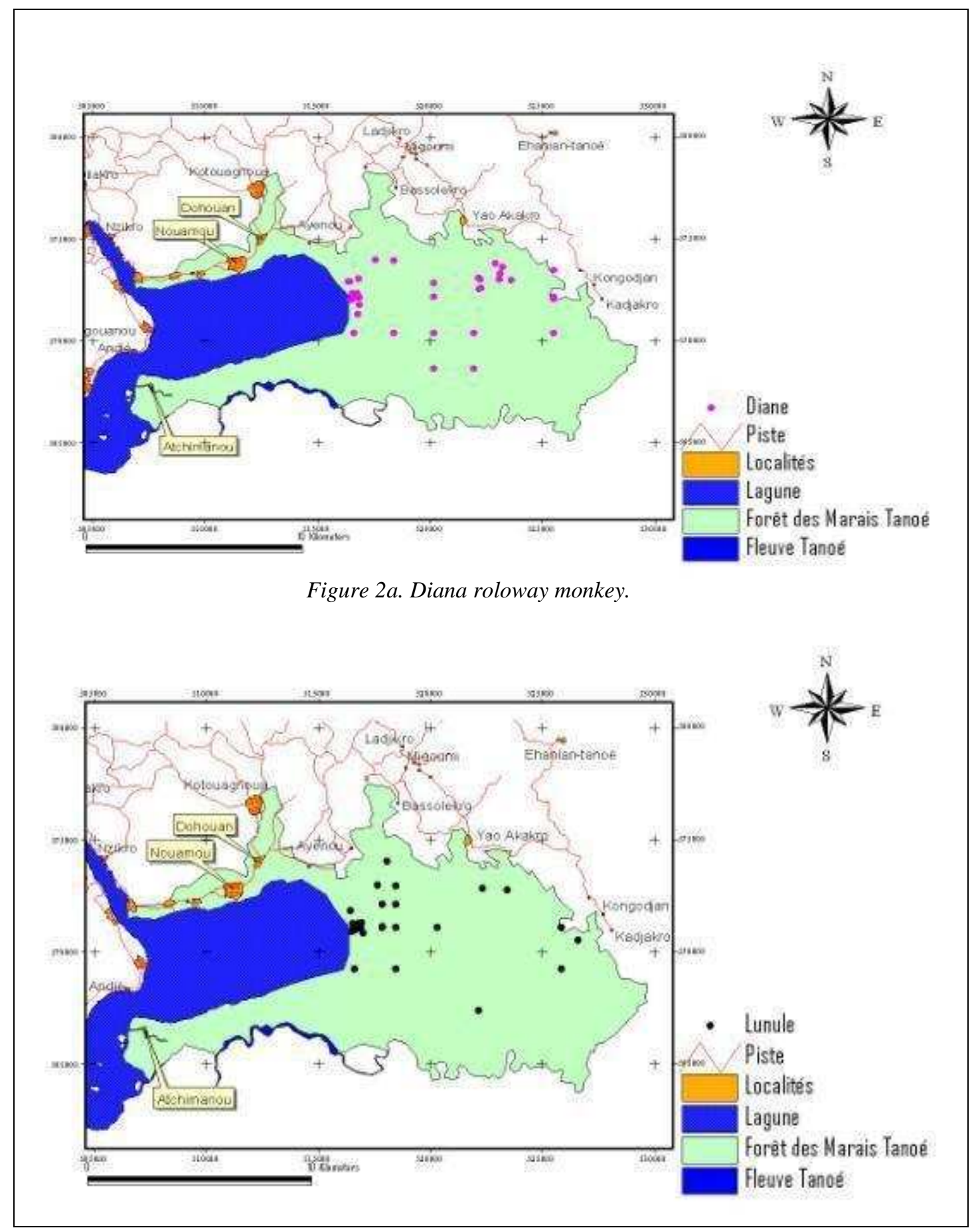

Figure 2b. White napped mangabey.

Figure 2: Distribution of two critical endangered primate species in the Tanoe Swamp forest. 


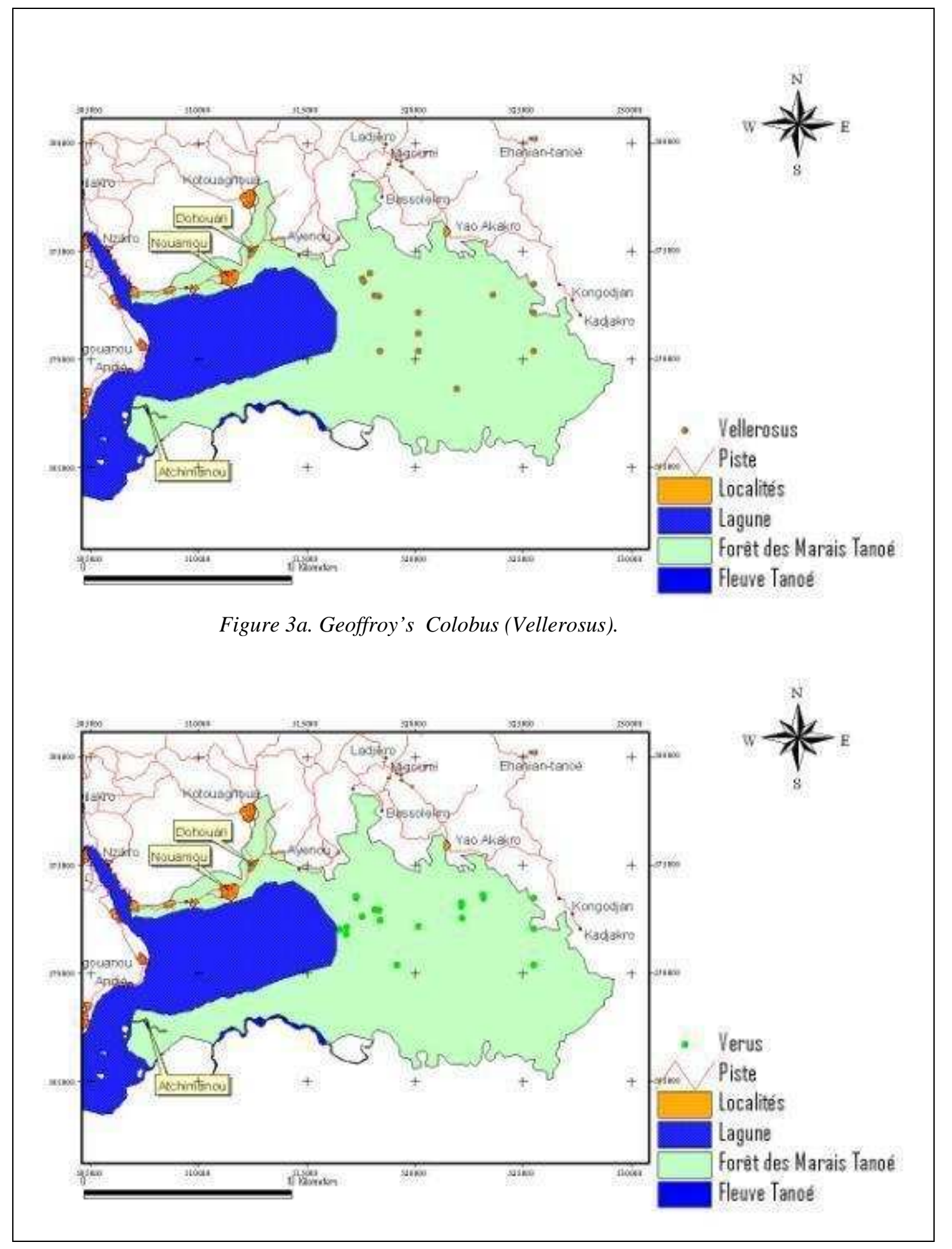

Figure 3b. Olive Colobus (verus).

Figure 3: Distribution of two primate species with conservation concern in the Tanoé Swamp forest. 
Table 1: Number of observations of primate evidence and number of group in the TSF.

\begin{tabular}{|c|c|c|c|c|c|c|}
\hline \multirow[t]{2}{*}{ Common name } & \multirow[t]{2}{*}{ Scientific name } & \multirow{2}{*}{$\begin{array}{c}\text { Number of } \\
\text { observations }\end{array}$} & \multirow{2}{*}{$\begin{array}{c}\text { Number of } \\
\text { group }\end{array}$} & \multicolumn{3}{|c|}{ Types of observation } \\
\hline & & & & visual & audible & tracks \\
\hline Miss Waldron red colobus & Piliocolobus badius waldronii & 1 & 1 & 0 & 1 & 0 \\
\hline Olive colobus & Procolobus verus & 29 & 24 & 16 & 13 & 0 \\
\hline Geoffroy white thighed colobus & Colobus vellerosus & 26 & 26 & 17 & 9 & 0 \\
\hline Roloway Diana guenon & Cercopithecus diana roloway & 85 & 69 & 38 & 47 & 0 \\
\hline Campbell's Lowe & Cercopithecus campbelli lowei & 155 & 123 & 50 & 105 & 0 \\
\hline Lesser Spot-nosed monkey & Cercopithecus petaurista petaurista & 82 & 71 & 52 & 30 & 0 \\
\hline White napped mangabey & Cercocebus atys lunulatus & 45 & 37 & 12 & 32 & 1 \\
\hline
\end{tabular}

Table 2: Frequency of encounter and relative abundance of the observed primate species in the TSF.

\begin{tabular}{|c|c|c|c|c|c|c|}
\hline Common name & Scientific name & Observations & $\begin{array}{c}\text { Frequency of } \\
\text { observation }\end{array}$ & $\begin{array}{c}\text { Number of } \\
\text { group }\end{array}$ & $\begin{array}{c}\text { Frequency of } \\
\text { group } \\
\text { encounter }\end{array}$ & $\begin{array}{c}\text { Relative } \\
\text { abundance }\end{array}$ \\
\hline Miss Waldron red colobus & Piliocolobus badius waldronii & 1 & 0,002 & 1 & 0,001 & 0,002 \\
\hline Olive colobus & Procolobus verus & 29 & 0,069 & 24 & 0,032 & 0,048 \\
\hline Geoffroy's colobus & Colobus polykomos polykomos & 26 & 0,061 & 26 & 0,035 & 0,052 \\
\hline Roloway Diana guenon & Cercopithecus diana roloway & 85 & 0,201 & 69 & 0,092 & 0,139 \\
\hline Campbell's Lowe & Cercopithecus campbelli lowei & 155 & 0,366 & 123 & 0,164 & 0,248 \\
\hline Lesser Spot-nosed monkey & Cercopithecus petaurista petaurista & 82 & 0,194 & 71 & 0,095 & 0,143 \\
\hline White napped mangabey & Cercocebus atys lunulatus & 45 & 0,107 & 37 & 0,049 & 0,075 \\
\hline
\end{tabular}


Table 3: Frequency of polyspecific associations of monkey in the TSF.

\begin{tabular}{lccccccc}
\hline Association & Dia-Lun & Dia-Ver & Ver-Vel & Ver-Lun & Dia-Bad & Dia-Vel & Total \\
\hline $\mathrm{N}$ & 10 & 7 & 2 & 1 & 1 & 1 & 22 \\
Frequency & 45,45 & 31,82 & 9,11 & 4,54 & 4,54 & 4,54 & 100 \\
\hline
\end{tabular}

Table 4: GPS coordinates of the polyspecific association of TSF monkeys.

\begin{tabular}{|c|c|c|c|c|c|}
\hline Date & Time & Observation type & Species & $\mathbf{X}$ & $\mathbf{Y}$ \\
\hline 04/March/2008 & $11 \mathrm{H} 22$ & Heared & dia & 516535 & 571235 \\
\hline 04/March/2008 & $11 \mathrm{H} 24$ & Seen & lun & 516535 & 571235 \\
\hline 29/Fevruary/2008 & $16 \mathrm{H} 10$ & Seen & dia & 516560 & 570908 \\
\hline $29 /$ Fevruary/2008 & $16 \mathrm{H} 10$ & Seen & ver & 516560 & 570908 \\
\hline 11/March/2008 & 8 H 34 & Seen & lun & 516584 & 571070 \\
\hline 11/March/2008 & $8 \mathrm{H} 37$ & Heared & dia & 516584 & 571070 \\
\hline 05/March/2008 & 8 H 35 & Heared & dia & 516672 & 571093 \\
\hline 05/March/2008 & 8 H 35 & Seen & lun & 516672 & 571093 \\
\hline 04/March/2008 & $16 \mathrm{H} 08$ & Seen & dia & 516673 & 571170 \\
\hline 04/March/2008 & $16 \mathrm{H} 08$ & Seen & lun & 516673 & 571170 \\
\hline 05/March/2008 & $15 \mathrm{H} 20$ & Seen & lun & 516682 & 571053 \\
\hline 05/March/2008 & $15 \mathrm{H} 22$ & Heared & dia & 516682 & 571053 \\
\hline 05/March/2008 & 7 H 26 & Heared & lun & 516716 & 571000 \\
\hline 05/March/2008 & 7 H 30 & Heared & dia & 516716 & 571000 \\
\hline $27 /$ Fevruary/2008 & $9 \mathrm{H} 23$ & Heared & dia & 516890 & 571027 \\
\hline $27 /$ Fevruary/2008 & $9 \mathrm{H} 23$ & Heared & ver & 516890 & 571027 \\
\hline $28 /$ Fevruary/2008 & $11 \mathrm{H} 13$ & Heared & ver & 518222 & 571849 \\
\hline $28 /$ Fevruary/2008 & $11 \mathrm{H} 30$ & Heared & vel & 518222 & 571849 \\
\hline 28/Fevruary/2008 & $10 \mathrm{H} 55$ & Heared & ver & 518430 & 571826 \\
\hline 28/Fevruary/2008 & $10 \mathrm{H} 33$ & Heared & vel & 518430 & 571826 \\
\hline 21/March/2008 & $8 \mathrm{H} 30$ & Seen & dia & 522410 & 572010 \\
\hline 21/March/2008 & $8 \mathrm{H} 30$ & Heared & ver & 522410 & 572010 \\
\hline 24/March/2008 & $9 \mathrm{H} 30$ & Seen & dia & 522448 & 571465 \\
\hline 24/March/2008 & 9 H 30 & Seen & ver & 522448 & 571465 \\
\hline 13/March/2008 & $16 \mathrm{H} 02$ & Heared & lun & 516624.51 & 569210.77 \\
\hline 13/March/2008 & $16 \mathrm{H} 02$ & Heared & dia & 516624.51 & 569210.77 \\
\hline 15/March/2008 & $11 \mathrm{H} 35$ & Seen & dia & 518470.72 & 572895.65 \\
\hline
\end{tabular}




\begin{tabular}{|c|c|c|c|c|c|}
\hline 15/March/2008 & $11 \mathrm{H} 45$ & Heared & $\operatorname{lun}$ & 518470.72 & 572895.65 \\
\hline 29/Fevruary/2008 & $9 \mathrm{H} 05$ & Heared & ver & 520318.33 & 571053.95 \\
\hline 29/Fevruary/2008 & $9 \mathrm{H} 05$ & Heared & lun & 520318.33 & 571053.95 \\
\hline 05/March/2008 & $10 \mathrm{H} 24$ & Heared & dia & 520318.33 & 571053.95 \\
\hline 05/March/2008 & $10 \mathrm{H} 24$ & Heared & wald & 520318.33 & 571053.95 \\
\hline 13/March/2008 & $8 \mathrm{H} 23$ & Heared & dia & 522166.62 & 567370.08 \\
\hline 13/March/2008 & $8 \mathrm{H} 23$ & Heared & lun & 522166.62 & 567370.08 \\
\hline 23/March/2008 & $14 \mathrm{H} 30$ & Seen & dia & 525859.77 & 570932.95 \\
\hline 23/March/2008 & $14 \mathrm{H} 30$ & Seen & ver & 525859.77 & 570932.95 \\
\hline 19/March/2008 & $10 \mathrm{H} 40$ & Seen & dia & 525859.23 & 572406.72 \\
\hline 19/March/2008 & $10 \mathrm{H} 40$ & Seen & vel & 525859.23 & 572406.72 \\
\hline 19/March/2008 & $10 \mathrm{H} 40$ & Seen & ver & 525859.23 & 572406.72 \\
\hline 21/March/2008 & $8 \mathrm{H} 29$ & Heared & lun & 525860.40 & 569213.55 \\
\hline 21/March/2008 & 8 H 29 & Heared & dia & 525860.40 & 569213.55 \\
\hline 23/March/2008 & $9 \mathrm{H} 55$ & Seen & ver & 525860.40 & 569213.55 \\
\hline 23/March/2008 & $9 \mathrm{H} 55$ & Seen & dia & 525860.40 & 569213.55 \\
\hline 01/March/2008 & $11 \mathrm{H} 30$ & Seen & dia & 610861.15 & 552713.38 \\
\hline 01/March/2008 & $11 \mathrm{H} 30$ & Seen & ver & 610861.15 & 552713.38 \\
\hline
\end{tabular}

\section{DISCUSSION}

South-central and eastern Côte d'Ivoire in the eastern part of the Upper Guinea hotspot are reported to be part of the original range of three critically endangered primate species: the Diana roloway (Cercopithecus diana roloway), the white-napped mangabey (Cercocebus atys lunulatus) and the Miss Waldron's red colobus (Piliocolobus badius waldronae). However, no significant conservation effort has been made so far on the behalf of these monkeys and they are increasingly threatened by human activities. Updates on the current distribution and conservation status of these primates and the identification of sites for primate conservation are urgently needed. Thanks to a collaboration between CEPA (Conservation des Espèces et Populations Animales: www.association- cepa.org) and the CSRS (Centre Suisse de Recherches Scientifiques en Côte d'Ivoire: www.csrs.ch), surveys were conducted from 2004 to 200714 selected forests of southcentral and eastern Côte d'Ivoire to seek evidence for primates of conservation concern.

In this study, seven primate species have been confirmed with three that are classified as Critically Endangered by the IUCN 2008 (Cercopithecus Diana roloway, Cercocebus atys lunulatus and Piliocolobus badius waldronae), two are Near Threatened (Colobus vellerosus and Procolobus verus) and two are Least Concern (Cercopithecus campbelli lowei and C. petaurista petaurista). Côte d'Ivoire, with twenty three taxa, presents one of the highest diversity in primate species in West Africa, with some of these species 
endemic to this country. Within these species, two colobine taxa are on the verge of extinction: Procolobus badius waldronae and Colobus polykomos dollmani (Gonedelé Bi et al., 2006, 2010). After surveying the whole forest area of Côte d'Ivoire for more than a decade, our team concluded that the "Tanoé Swamp Forest" must be considered as a High Conservation Value Forest (Gonédélé Bi et al., 2008). Unfortunately this forest is facing several threats and it is not protected.

This forest represents a unique opportunity for the world scientists and conservationists for the survival of endangered primate species. This forest inhabits at least three of the 25 most threatened primates species in the world (McGraw and Oates, 2009). It is the latest refuge known of the Miss Waldron red colobus monkey (McGraw, 2005). Even if we have heard only vocalizations during our exploration, we believe that there are viable populations in the forest, and so more attention can be paid to the hunters who affirm the presence of viable population. For these hunters, it very difficult to meet the Miss Waldron red colobus monkey because it became very cryptic and noiseless (Koné et al., 2006); Béné and Akpatou, 2007; Béné et al., 2007).

In addition, two other Critical Endangered monkey species have been confirmed: the Diane Roloway monkey and White-napped mangabey are exceptionally abundant in the forest. So far, this is the only forest in Côte d'Ivoire that still housing the Diane Roloway monkey, even if it presence is suspected in some forests like Dassioko FC, Niégré FC and Maby Yaya FC (Koné and Akpatou, 2004). Regarding the White-napped mangabey, it presence was confirmed in another forest (the Dassioko FC) and suspected in other forests.
Furthermore, two monkey species Near Threatened according to INCN 2008 were also met in the Tanoé Forest. Interesting population of Olive colobus has been reported on the non protected islands of the Sanssandra River (Koné et al. 2005), but to date, we can say that the Tanoé Forest is the second forest inhabiting the most population of this monkey species after the Taï National Park. And Geoffroy Black-and-white colobus monkey has been encountered anywhere else during the surveys in different forests of Côte d'Ivoire. For Gonedelé Bi et al., (2006), these two species must be listed as endangered by IUCN.

As it is shown in the distribution maps, the Tanoé Forest is a very important refuge for the monkeys. Indeed, whatever the species of monkey considered, the groups encountered are almost throughout the forest (except for Miss Waldron red colobus monkey for which only few vocalizations have been heard near the lagoon Ehy). However, there is a higher concentration of monkeys on the side of the lagoon. One of the reasons that could explain this situation is the difficulties to access for human because of the inundation of the forest throughout all the year. Even during the dry season, some places in this zone are completely inaccessible. It constitutes a natural barrier of protection for these monkeys.

The different monkeys of the Tanoé Forest have been found sometimes in polyspecific association during the fieldwork. No study has been made on the reasons of this behavior in the forest, but, this strategy is common to all species of monkeys in general, to reduce the risk of predation (Alexander, 1974; Terborgh and Janson, 1986; Dunbar 1988; Bshary and Noë, 1997a, b; Noë and Bshary, 1997). Indeed, several advantages are related to the formation of large groups. While this phenomenon has the disadvantage of 
increasing food competition, the risk of being quickly spotted by predators, however, it has advantages to offer a greater possibility of detecting the predator first (Terborgh and Janson, 1986), to increase the chance for individuals to escape an attack by the dilution effect, to confuse the predator by a leak disorderly and the possibility of organizing collective defenses (Boesch and Boesch, 1989; Boesch, 1994).

\section{Conclusion}

Our study allowed us to confirm the presence of seven species of monkeys in the forest of Marais Tanoé. Among these monkeys, three are classified as Critical Endangered by IUCN (Cercopithecus Diana roloway, Cercocebus atys lunulatus and Piliocolobus badius waldronae), two are Near Threatened (Colobus vellerosus and Procolobus verus) and two others are Least Concern (Cercopithecus campbelli lowei and C. petaurista petaurista). These monkeys are encountered everywhere in the forest. Three species (...) are more abundant compared to the others, but in any case they form polyspecific association. Some of these monkeys' species have never been studied in world. Tanoé Forest is a High Conservation Value Forest. It represents a precious asset for research and for the promotion of sustainable development in the region. Feeling concerned by the survival of the unique biodiversity of the Tanoé Forest and by the fate of the human communities, the future of whom is directly or indirectly linked with that of the forest, we urge the Ivorian authorities to consider the conservation of the Tanoé Forest as a top priority.

\section{ACKNOWLEDGEMENTS}

Our first thanks go to CEPA (Conservation des Espèces et Populations Animales) that requested and funded this study and in particular its President, JeanMarc Lernould for the confidence he has placed in us. We are grateful to CSRS for it collaboration with CEPA and for ensuring the administrative, financial and logistics of the study. We thank the Research Department at the Ministry of Scientific Research for having issued an authorization to the study. We also want to thank WAPCA (West African Primate Conservation Association) and the Zoo of Mulhouse for their financial support Our thanks go to Mr. Joel Gamys for reviewing the level of language.

\section{REFERENCES}

Adou Yao CY, Février. 2007. Mission d'inventaire préliminaire de la faune et de la flore de la Forêt des Marais Tanoé (1327). Partie II : Inventaire préliminaire de la flore et description de la végétation. Rapport de mission CEPA/RASAP-CI. 34.

Alexander RD. 1974. The evolution of social behaviour. Ann. Rev. Ecol. Syst., 5: 325383.

Avenard EM, Girard G, Touchebeuf P, Guillaumet JL, Adjanohoun E, Perraud, A. 1971. Mémoire ORSTOM n ${ }^{\circ}$ 50: Paris France; 329.

Béné JCK. Akpatou KB. 2007. Mission d'inventaire préliminaire de la faune et de la flore de la Forêt des Marais Tanoé (1327). Partie I : Inventaire Préliminaire de la faune avec un accent particulier sur les primates. Rapport de mission CEPA/RASAP-CI, 29.

Béné JCK, Koffi DA, Akpatou KB. 2007. Evaluation (after six months) of the bordering population knowledge and attitude in relation with wildlife conservation. Report for CEPA Côte d'Ivoire, Abidjan, 20p.

Boesch C, Boesch H. 1989. Hunting behavior of wild chimpanzees in the Taï National Park. Am. J. Phys. Anthr., 78: 547-573. 
Boesch C. 1994. Chimpanzees-Red colobus: A predator-prey system. Anim. Behav., 47: 1135-1148.

Bshary R, Noë R. 1997a. Anti-predation behaviour of red colobus monkeys in the presence of chimpanzees. Behav. Ecol. Sociobiol., 41: 321-333.

Bshary R, Noë R. 1997b. Red colobus and diana monkeys provide mutual protection agaisnt predators. Anim. Behav., 54: 1461-1474.

Cowlishaw G. 1999. Predicting the pattern of decline of African primate diversity: an extinction debt from historical deforestation. Conserv. Biol., 13: 11831193.

Dunbar RIM. 1988. Evolution of grouping patterns. In Primate Social Systems. Croom Helm: London, Sydney; 106-150.

Gonédélé Bi S, Bitty AE, Gnangbé F, Béné JCK, Koné I, Sangaré A, Zinner D. 2010. Conservation status of Geoffroy's pied colobus monkey (Colobus vellerosus Geoffroy 1834) has dramatically declined in Côte d'Ivoire. African Primates, 7 (1): 19-26

Gonédélé Bi S, Koné I, Béné JCK., Bitty AE, Akpatou BK, Goné Bi Z, Ouattara K, Koffi DA. 2008. Tanoé forest, southeastern Côte-d'Ivoire identified as a high priority site for the conservation of critically endangered Primates in West Africa, Trop. Conserv. Sci., 1(3): 263276.

Gonedelé Bi S, Zinner D, Koné I, Goné Bi Z, Akpatou KB, Béné JCK, Sangaré A, Boesch C. 2006. A West african Blackand-White Colobus monkey, Colobus polykomos dollmani Schwarz, 1927, Facing Extinction. Primate Conserv., 21: $55-61$.

Gonedelé Bi S, Anderson B, Kone I, Abdourahmane S, Dietmar Z, Akpatou B, Béné JCK, Eliezer N, Boesch C, 2008.
Distribution and conservation status of the primates of Côte d'Ivoire (West Africa). IUCN: the Red List of Threatened Species 2008.

Koné I, Béné JCK, Bitty EA. 2006. Survey in the extreme South-East of Côte d'Ivoire to evaluate the conservation status of Piliocolobus waldronae, Cercocebus atys lunulatus and Cercopithecus diana roloway: Case of the non protected forest of the lagoon Ehy, the Forest Reserve of N'gandan and the Ehotile Island National Park. Report for CEPA Côte d'Ivoire, Abidjan, 16.

Koné I, Akpatou BK. 2004. Identification des sites abritant encore les singes Cercopithecus diana roloway, Cercocebus atys lunulatus et Piliocolobus badius waldronae en Côte-d'Ivoire. Rapport final pour CEPA, 42.

Koné I, Béné JCK, Bitty EA. 2005. Survey in the costal forests of Côte d'Ivoire to confirm the presence of Piliocolobus waldronae, Cercocebus atys lunulatus and Cercopithecus diana roloway: case of the Forest Reserve of Dakpadou, Natural Private Park of Gaoulou and the non protected islands of Sassandra River near Gaoulou. Report for CEPA Côte d'Ivoire Abidjan, 13.

McGraw WS, Oates JF. 2009. Roloway Guenon. In Primates in Peril: The World's 25 Most Endangered Primates 2008-2010. Mittermeier RA, Wallis J, Rylands AB, Ganzhorn J, Oates JF, Williamson E, Palacios E, Heymann EW, Kierulff MCM, Yongcheng L, Supriatna J, Roos C, Walker S, Cortes-Ortiz L, Schwitzer C. (eds). IUCN/SSC Primate Specialist Group: Arlington, VA; 92.

McGraw WS. 2005. Update on the search for Miss Waldron's red Colobus monkey. Int. J. Primatol., 26: 605-619. 
McGraw WS, Monah IT, Abedi-Lartey M. 1998. The survey of endangered primates in the forest reserves of eastern Côte d'Ivoire. Afr. Primates, 3: 22-25.

Myers N, Mittermeier RA, Mittermeier CG, da Fonseca GAB, Kent J. 2000. Biodiversity hotspots for conservation priorities. Nature, 403: 853-858.

Noë R, Bshary R. 1997. The formation of red colobus-diana monkey associations under predation pressure from chimpanzees. Proc. R. Soc. Lond. B., 264: 253-259.

Oates JF, Adedi-Lartey M, Scott MW, Struhsaker TT, Whitesides GH. 2000.
Extinction of the West African red colobus monkey. Conserv. Biol., 14: 1526-1532.

Terborgh J, Janson CH. 1986. The socioecology of Primate groups. Annu. Rev. Ecol. Syst., 17: 111-135.

Yao, T. Brou, Oszwald, J., Bigot S. et Servat E. 2005. Risques de déforestation dans le domaine permanent de l'état en côte d'ivoire : quel avenir pour ces derniers massifs forestiers. Télédétection, 5(1-23): 105-121. 